\title{
The Rule of Law and Economic Development
}

\author{
Stephan Haggard, ${ }^{1}$ Andrew MacIntyre, ${ }^{2}$ \\ and Lydia Tiede ${ }^{3}$ \\ ${ }^{1}$ Graduate School of International Relations and Pacific Studies, University \\ of California at San Diego, La Jolla, California 92093-0519; email: shaggard@ucsd.edu \\ ${ }^{2}$ Crawford School of Economics and Government, Australian National University, \\ Canberra ACT 0200, Australia; email: amacintyre@anu.edu.au \\ ${ }^{3}$ Department of Political Science, University of California at San Diego, La Jolla, \\ California 92093-0521; email: ltiede@ucsd.edu
}

Annu. Rev. Polit. Sci. 2008. 11:205-34

First published online as a Review in Advance on January 8, 2008

The Annual Review of Political Science is online at http://polisci.annualreviews.org

This article's doi:

10.1146/annurev.polisci.10.081205.100244

Copyright (c) 2008 by Annual Reviews.

All rights reserved

$1094-2939 / 08 / 0615-0205 \$ 20.00$

\section{Key Words}

governance, property rights, contracts, corruption, long-run growth, legal origins

\begin{abstract}
With the enormous expansion of scholarship on this subject, "rule of law" has come to mean different things—ranging from security and order to the operations of courts and the administration of justice. We review the various streams of theoretical and empirical research by academics and practitioners, emphasizing the connections to economic development. The core logic is that security of property rights and integrity of contract underpin, respectively, investment and trade, which in turn fuel economic growth and development. However, property rights and contracts rest on institutions, which themselves rest on coalitions of interests. Formal institutions are important, but, particularly in developing countries, informal institutional arrangements play a significant part as well. These considerations lead us to caution against an exaggerated confidence in the ability of development assistance to implant new institutions for the rule of law.
\end{abstract}




\section{INTRODUCTION}

The surge of interest in the relationship between the rule of law and economic growth is the result of a confluence of developments both outside and inside the academy. Democracy promotion since the end of the Cold War has been accompanied by efforts to advance the rule of law for security and political as well as economic reasons. The international financial institutions and national aid agencies have also made rule-of-law programs a central component of the broader effort to reform governance in the interest of growth and poverty alleviation.

The core theoretical driver of the scholarly literature has been the renewed interest in the institutional underpinnings of long-run growth. This literature has drawn most centrally on the observation that property rights and the security of contract matter to sustained economic expansion. Yet, to political scientists, this consensus appears vulnerable to the same criticisms that proponents of the new growth theory leveled against their neoclassical predecessors. Property rights and the enforcement of contract are clearly endogenous to some underlying political bargains and institutions.

This essay explores these connections through an examination of what we call the rule-of-law complex: the set of complementary institutions that support the rule of law as most broadly conceived. In the first section below, we review the theory and evidence surrounding property rights and security of contract. In the next four sections, we turn to the broader political, institutional, and legal underpinnings of property rights and their effective enforcement, beginning with the most fundamental Hobbesian problem of order. We then turn to challenges that arise from private capture of the state and corruption, the question of how to check state power, and the design of legal and judicial institutions more narrowly conceived.

When discussing the rule of law, both scholars and practitioners focus primarily on formal institutions. In the sixth section, we briefly review how informal institutions may substitute for formal legal systems. A key question is whether such institutions are second-best adaptations to environments characterized by weak formal governance, or whether they constitute an efficient alternative to formal institutions.

We conclude by considering what the literature on the rule of law and economic development might contribute to the policy debate. The initial enthusiasm about the gains from improving legal institutions has been followed by a wave of skepticism, much of it focused implicitly on problems of endogeneity. If the efficacy of legal institutions depends on complementary features of the broader political system, apparently simple reforms may be well beyond the capacity of outsiders to effect.

In the Appendix, we briefly introduce some rule-of-law indicators that have been used in cross-national quantitative work. This methodological discussion parallels our article's main points. These different rule-of-law and legal institution indicators measure different facets of a country's legal system and are less tightly correlated than might be thought. Moreover, these measures are not closely correlated with some of the institutions deemed central to the rule of law, such as checks and balances. These problems are not trivial; prominent empirical findings may not be robust to alternative specifications using different rule-of-law measures (Tiede 2007).

\section{THE CORE: PROPERTY RIGHTS, CONTRACTING, AND ECONOMIC GROWTH}

The core theoretical insight linking law to economic development runs through two distinct but closely related channels: the effects of property rights on investment and the effects of contract enforcement on trade. References to the role of the state as an enforcer of property rights and contracts can be found in classic political economy. But it was not until 
the 1960s that work by Coase (1960), Alchian (1965), Demsetz (1967, Alchian \& Demsetz 1973), Williamson $(1971,1985)$ and others laid the groundwork of the new institutional economics, of which property rights and contract design and enforcement constituted a core component (for reviews and syntheses, see Furubotn \& Pejovich 1972, Barzel 1997). These innovations were followed by important applications in the new economic history, of which North was the most influential proponent (North \& Thomas 1973; North 1981, 1990; see also Haber et al. 2003). In North's accounts, secure rights in property were the key to sustained economic growth. These ideas enjoyed yet another revival with the strand of the new growth theory that focused on the role of institutions (Acemoglu et al. 2001, 2005; Rodrik et al. 2002; Easterly \& Levine 2003; Helpman 2004 for an overview of the new growth literature).

As the theoretical ideas underlying this approach have been outlined eloquently elsewhere (most notably Williamson 1985 and Barzel 1997), we can treat them briefly. Property rights are social institutions that define the privileges individuals and other legal entities, such as firms, ${ }^{1}$ enjoy with respect to a given allocation of resources. Property rights are typically thought to constitute a "bundle" of more discrete rights that can be disaggregated in a variety of ways, most generally into rights of control and rights over income. The capacity to contract is equally fundamental. Some trade can take place in the form of barter or exchanges in which transactions clear immediately, but more complex transactions require the ability to make and receive promises about future actions. This is particularly true of financial transactions, which, from a legal point of view, are primarily contracts.

The link between property rights, the integrity of contract, and economic growth comes through several channels, but incen-

\footnotetext{
${ }^{1}$ For the purpose of this discussion, we bracket the complex issue of communal or collective property rights and the collective action problems surrounding them.
}

tives play a central role: The more welldeveloped and secure are property rights, the greater incentives individuals have to invest. Secure property rights and the capacity to contract over time and space also permit trade and a corresponding increase in the efficiency of resource allocation, including through the development of the financial system.

It is not altogether clear how to think about property rights or the integrity of contract as a causal variable, however. Glaeser et al. (2004) have argued that property rights should not be seen as institutions at all. They reference North's (1981, pp. 201-2) definition of institutions as a set of rules, compliance procedures, and norms "designed to constrain the behavior of individuals in the interests of maximizing the wealth or utility of principals." Glaeser et al. claim that property rights do not constrain actors; rather, they result from other institutions or simply reflect policy choices. We endorse the view that property rights are endogenous, but they are nonetheless institutions in the Northian sense. Property rights and security of contract constitute powerful constraints on the behavior of both the state and private agents, but only when they are consistently enforced.

Time inconsistency problems abound in economic life, and they are crucial to understanding the significance of the rule of law in the new institutional economics. Investments can be expropriated, and contracts can be broken. Individuals can protect their own property or reach self-enforcing bargains to address these risks, but the costs of monitoring and enforcement and the effects of uncertainty can easily outweigh the gains from investment and trade. Credible third-party enforcement of property rights and contract increases private returns, extends time horizons, and deters opportunistic behavior. As Ferejohn \& Pasquino (2003, p. 242) put it, the predictability of law through its consistent application and enforcement allows people "to foresee accurately the consequences of their actions and not be subject to sudden surprises." 
The cross-national empirical literature on property rights and growth is easily summarized as there have been relatively few contrarian voices. More robust property rights protection-typically measured through survey data on risk of expropriation (e.g., from the International Country Risk Guide) or including risk of expropriation as a component of a wider index (per Kaufmann 2003a,b) — are indeed associated with better long-run economic performance (Knack \& Keefer 1995; Scully 1988; Clague et al. 1996, 1999; Zak \& Knack 2001; Keefer \& Knack 2002; Keefer 2007). The new literature on institutions and long-run growth tests similar propositions, since either the conception of institutions or the proxy for them is the extent of property rights protection (e.g., Acemoglu et al. 2001). In an interesting extension, Acemoglu \& Johnson (2005) find that the effects of property rights on growth, investment, and financial development trump the effects of institutions ensuring the integrity of contracts. In addition to the focus on long-run growth, variants of the property rights literature have also considered alternative dependent variables, including productivity (Hall \& Jones 1999) and investment in fixed assets (Claessens \& Laeven 2003).

Had Acemoglu et al. (2001) simply regressed a measure of expropriation risk on gross domestic product (GDP) per capita in a cross-section of countries, it is highly doubtful that their paper would have found its way into the American Economic Review. A central contribution is in the way the authors address the endogeneity of institutionsthe possibility that economic growth determines the level of property rights protection. They argue that settler mortality in the eighteenth and nineteenth centuries provides a purely exogenous instrument for solving this problem. They hypothesize-but by no means demonstrate - that high settler mortality reflected unappealing environments that generated "extractive" political institutions and correspondingly weak property rights protection. By contrast, low settler mortality produced "neo-Europes" that imported more favorable institutions. According to Acemoglu et al., these (hypothesized) early institutions proved remarkably persistent; the authors demonstrate a very strong causal influence from settler mortality to current measures of expropriation risk.

Despite the caution with which Acemoglu et al. approach the endogeneity question, there is no consensus that they have eliminated the possibility of reverse causality - that growth is the underlying determinant of the improvement in the quality of property rights rather than the other way around-or other causal factors that affect growth independently of their effects on institutions. These include human capital (Glaeser et al. 2004) and the direct effects of resource endowment and other environmental constraints (e.g., Sachs 2003).

There may be room to extract more information from existing or new cross-national data sets, but a promising alternative is the turn toward micro-level work. These studies avoid some of the specification problems common in the cross-national literature, particularly by exploiting natural experiments or even fully randomized designs. As this new micro literature on property rights is growing rapidly, we can only convey the flavor of some of the more innovative studies. First, there is a long tradition of work on how variations in the nature and security of property rights in land affect investment, labor effort, and productivity (Cheung 1963, 1969). Besley (1995) exploits differences in transfer rights in two regions of Ghana to show how self-reported rights (to sell, rent, mortgage, and so on) affect investment. Alston \& Schneider (1996) show how the grant of formal title in several frontier areas of Brazil affected land prices and how land prices in turn affected demand for title (see also Anderson \& Hill 1975, Libecap 1989).

The interest in rural titling has recently extended to urban areas, thanks in part to the advocacy of de Soto (2000). In an almost pure natural experiment, Fields (2004, 
2005,2008 ) has exploited the gradual expansion of a nationwide titling program in Peru to test for the effects of secure property rights on a series of behaviors, from investment to labor supply and even fertility (see also Galiani \& Schargrodsky 2006). One of her more startling findings was that residents of squatter settlements in Lima were constrained to spend time in their homes because of fear of private encroachment.

Finally, Johnson et al. (2002) survey firms across five postsocialist countries in Europe (Poland, Romania, Slovakia, the Ukraine, and Russia) that were presumed to differ in their level of property rights protection. Survey questions asked about corruption, payments for protection, and the ability to use courts for redress. Both higher under-the-table payments and the perceived ineffectiveness of courts had adverse effects on reinvestment from retained earnings.

In summary, there seems to be a reasonably strong consensus that property rights matter, supported by both cross-national and survey work. But there is also concern that the security and enforcement of property rights might be wholly endogenous to some antecedent political conditions, or that the effects of property rights are at least conditional on other, complementary institutions. We begin with the most fundamental question of order.

\section{THE RULE OF LAW AS THE PROVISION OF SECURITY}

For the early contract theorists, but most notably for Hobbes, the state of nature was characterized by continuing and ongoing threats to personal security as well as property. In a telling fable, Hobbes notes how security is bounded by the need to sleep and the corresponding impossibility of individually guarding against all possible threats to person and property. There is a deep logic in this view; it makes little sense to talk about security of property or the integrity of contract if the economic agents engaging in these activities are not secure. If the rule of law means anything, it must mean in the first instance the security of person, and a number of legal scholars have noted as much (Narayan et al. 2000, Black et al. 2000, Belton 2005).

Unfortunately, the breakdown of central authority and the emergence of civil conflict and anarchy are not just a fable. A small but intriguing theoretical literature has begun to explore the economic effects, in different formulations, of anarchy (Hirshleifer 1995), extortion (Konrad \& Skaperdas 1998), private predation (Grossman \& Kim 1995), and lawlessness (Dixit 2004). But it has taken the work of Collier (1999, Collier et al. 2003) to show just how devastating the effects of civil conflict can be. ${ }^{2}$ First, civil war involves the diversion of resources from productive private activity and the provision of public goods, such as infrastructure and education, into the means of violence. Second, these diverted resources are devoted to the destruction of both public infrastructure and private property-often intentionally—and makes it impossible to engage in productive activity and trade. Third, civil conflict and the breakdown of order provide cover for criminal activity, private violence, and vendetta. Fourth, the loss of human life is a loss of human capital, particularly as the incidence of casualties in civil conflicts has shifted relentlessly from combatants to civilians.

It is one thing to document the economic costs of civil conflict; it is quite another to reconstitute the rule of law in this most basic sense when it is lacking. Civil wars typically last a long time, and they appear to be lasting longer. In 1947, the average length for civil wars was two years; by 1999, that number had jumped to 15 years (Fearon \& Laitin 2003). The evidence also suggests that few civil wars end through negotiated settlement, perhaps as few as $20 \%$ (Walter 1997). The remainder end in decisive military victory for one side or

\footnotetext{
${ }^{2}$ Not surprisingly, Collier has also advocated a strongly revisionist theory of the causes of civil war, in which economic motivations of the combatants ("greed") trump political and social injustice ("grievances").
} 
the other. Moreover, recidivism is high: On average, $39 \%$ of states emerging from conflict return to conflict in the first five years, and another $32 \%$ return to conflict in the following five years (Collier et al. 2006).

Yet despite these long odds, external actors have come to play a substantial role in seeking to restore law and order in postconflict settings. A recurrent theme in the literature is the multiplicity of challenges these anarchic environments pose, the interdependence of the reforms required for enduring security, and the correspondingly paltry successes to date (see Samuels 2006 for an overview). The first challenge is a catch-22: The provision of adequate security is a precondition for other rule-of-law reforms to take root. A painful lesson learned, or not learned, from experiences in Panama, Bosnia, Kosovo, Afghanistan, and Iraq has been the extraordinarily high cost of failing to provide adequate forces and basic policing functions to deter residual violence and criminal behavior. The question of transitional justice-how to deal with crimes and abuses associated with the ancien regime or the conflict itself-also constitutes a highly contested set of early policy choices that can adversely influence the transition path if mishandled (Flournoy \& Pan 2002, Vinjamuri \& Snyder 2004).

Only when these transitional actions have been taken is it possible to talk about the complex interdependencies within rule-of-law and security sector programs more narrowly conceived (Samuels 2006): building a credible and neutral police force; developing public prosecutors and defenders; reforming the criminal code; ensuring the competence as well as independence of judges; and guaranteeing the integrity of the penal system.

A full explication of these issues goes beyond our central focus on the rule of law and economic development per se, but two points bear consideration. First, none of the studies that we have cited on the relationship between property rights and growth-nor any of those we cite in subsequent sections-control for overt conflict or other indicators of state failure. Those scholars who do intuit the primal importance of conflict for economic activity, such as Rodrik (1999), get at the issue indirectly through proxies such as ethnic heterogeneity. As a result, we really have no robust evidence that shortcomings with respect to property rights are a result of "bad" institutions or the much more fundamental problem of state failure and anarchy. This is hardly a trivial issue!

Second, the rich case study literature on rule-of-law programs in postconflict settings suggests strongly and repeatedly the practical implications of the endogeneity problem. As Samuels (2006, p. 17) summarizes in an outstanding review, "programs have typically focused on institutional objectives and formal legal structures without a nuanced understanding of the political and economic dynamics that prevented such structures from existing in the first place." This points to the need for outside parties to exercise caution when intervening in post-conflict settings - a theme we return to later. The practitioner literature is filled with war stories about how reforms of one sort-for example, of the criminal code or of formal judicial institutions-had marginal consequences in the absence of complementary reforms (see, e.g., Popkin 2000 on El Salvador; General Accounting Office 2001 on the former Soviet Union). ${ }^{3}$ In short, the underlying causal factors that generate civil war in the first place also severely constrain the ability of outsiders to reconstitute functioning legal systems.

\section{CORRUPTION OF THE RULE OF LAW}

If the provision of security constitutes the most fundamental conception of the rule of law, a close second is the principle of equal treatment and procedural fairness. Whatever

\footnotetext{
${ }^{3}$ One response to this problem has been renewed attention to indigenous institutions for managing conflict. See for example Hohe \& Nixon (2003) on East Timor and Sieder (2001) on Guatemala.
} 
law exists should be consistently applied across similar cases and economic agents (Dicey 1982, Holmes 2003). It would be naive to think that law is neutral in distributional terms. The emphasis here is on the consistent and nondiscriminatory application of the law-as captured in the pervasive image of "blind justice." This conception of the rule of law as procedural neutrality has become a central theme in discussions of governance, ${ }^{4}$ manifested most clearly in the current preoccupation with corruption.

There are circumstances in which corruption might enhance efficiency; think, for example, of a bribe designed to circumvent a distortionary tariff. However, there are a number of channels through which corruption can clearly have an adverse effect on economic activity through subversion of the law. First, if individuals cannot be confident of equal treatment by the judicial system, then the courts cease to be a dependable institution for dispute resolution, parties are forced back on the costly alternative of private enforcement, and investment and trade suffer accordingly. Second, rent-seeking and corruption raise costs for producers and consumers by diverting resources into the rent-seeking process (key theoretical treatments include Kreuger 1974, Bhagwati 1982, Shleifer \& Vishny 1998). Third and most important, corruption and rent-seeking introduce distortions that constitute barriers to long-run growth: monopolies, restrictions on entry, protectionism, misallocation of government spending, and private expropriation of assets through managerial malfeasance.

Research on corruption has expanded so rapidly since the mid-1990s that it has become a subfield of its own, fueled not only by scholars but through the initiatives of international development agencies and nongovernmental organizations (e.g., Transparency In-

\footnotetext{
${ }^{4}$ The US Agency for International Development has defined the rule of law in part by focusing on the predictability of the legal system and equal application of law to all people. See http://www.usaid.gov/our_work/democracy_and_ governance/technical_areas/rule_of_law.
}

ternational 2007). The study of corruption has also been transformed by an increasingly sophisticated array of data sets permitting crossnational empirical work. Mauro (1995) was influential in opening this line of research, showing that higher corruption as measured by subjective indices based on surveys of investors was associated with lower investment and growth. A stream of other studies followed (e.g., Knack \& Keefer 1995, Wei 1997, La Porta et al. 1999, Ades \& Di Tella 1997, Treisman 2000, Pellegrini \& Gerlagh 2004). Others extended the research to a variety of public sector outcomes, for example showing the adverse effects of corruption on education spending (Mauro 1998) and the quality of public infrastructure (Tanzi \& Davoodi 1997).

As with the literature on property rights, we are also seeing a number of micro-level studies based on more direct measures of corruption. These involve asking respondents not about their opinions of the level of corruption but about their actual experiences with it. Examples of this work include the joint World Bank and European Bank for Reconstruction \& Development (2007) Business Environment and Enterprise Performance Survey (BEEPS) on the transition economies and a variety of other techniques for measuring corruption, such as public expenditure tracking surveys that attempt to measure "leakage" to corruption (for an overview see Reinikka \& Svensson 2002, Reinikka 2001, Johnson et al. 2002). Other micro-level studies have sought out natural experiments that provide insight into the costs of corruption. In a cleverly designed study, Fisman (2001) tracks the stock prices of connected and nonconnected Indonesian firms following rumors that President Suharto had suffered a stroke in December 1997; connected firms witnessed a significantly sharper deterioration in overall valuation, in effect providing a direct measure of the value of cronyism.

Given that there are strong incentives to hide corrupt practices, it is rare to gain direct insight into the objectives of corrupt officials, which include not only private gain but also 
political objectives and the control of information. McMillan \& Zoida (2004) present a remarkable analysis based on detailed bribery records, captured in written agreements and on film, of Peru's notorious Secret Police chief Vladimiro Montesinos. The most striking feature of their analysis is how Montesinos allocated resources across different targets. Aggregate bribes to media companies were roughly 100 times higher than bribes to politicians and judges. McMillan \& Zoida conclude that the media constitute a more powerful check on corruption, because of their influence over public opinion, than do politicians.

The empirical findings with respect to the adverse effects of corruption on economic growth have achieved the status of received wisdom, and anticorruption strategiesunder the rubric of good governance and the rule of law-now lie near the center of the World Bank's institutional reform efforts. ${ }^{5}$ But, as with the apparently robust findings in the property rights literature, there is room for debate about the empirical foundations on which the cross-national findings rest. In a powerful review of the literature, Treisman (2007) finds that the cross-national findings about corruption rely largely on data sets measuring perceived corruption; substituting objective indicators based on surveys of actual experience with corruption yields much weaker results. Although perception indices capture what investors and analysts actually think, they may conflate a variety of discrete features of the business environment of which corruption is but one.

Also sitting somewhat uncomfortably with this consensus is the anomaly of

\footnotetext{
${ }^{5}$ Prior to his departure from the World Bank, Paul Wolfowitz was a vigorous champion of this agenda: "Corruption is often at the very root of why governments don't work. It weakens the systems and distorts the markets. In the end, governments and citizens will pay a price, in lower incomes, lower investment and more volatile economic swings. But when governments do work-when they tackle corruption and improve their rule of law-they can raise their national incomes by as much as four times" (World Bank 2006).
}

East Asia's rapid industrializers. Many of these countries-including Korea, Taiwan, Thailand, Malaysia, Indonesia, and now China and Vietnam-were characterized by extensive corruption during their transformative decades (Campos 2001, Rock \& Bonnett 2004). Why does corruption-and the absence of the rule of law more generallyappear to have debilitating effects in some settings but not others? One promising answer builds on the work of Shleifer \& Vishny (1993) to distinguish between different types of corruption. Centralized political institutions permit politicians to extract bribes but also provide incentives for leaders to limit arbitrary behavior on the part of lower-level officials. In effect, centralized systems are capable of creating a stable, predictable, and therefore credible regime for investors even if corruption is a component of the operating environment. When corruption is decentralized, by contrast, no individual politician or bureaucrat fully internalizes the costs of their corrupt behavior, and property rights are less secure as a result. Bardhan (1997, pp. 1324-26), Campos et al. (1999), and Rock \& Bonnett (2004) pursue this line of thinking. MacIntyre (2001) and Li \& Lian (2001) have undertaken detailed micro-level analysis showing how the Indonesian and Chinese experiences can be plausibly modeled in this way. Kang (2002) takes the further step of noting that centralized business organization may also serve to limit the capacity of the state to extract rents by establishing a "mutual hostage" framework between the state and the private sector.

The analysis of corruption has proven a rich entry point into de facto legal institutions. Moreover, the analysis of corruption underscores an important ambiguity in the property rights approach (Keefer 2004, Haber et al. 2003). Much of the property rights literature focuses on the security of property rights, but the corruption literature suggests it is possible to have secure property rights that favor an inefficient allocation of resources because of private capture. This lesson is particularly important to keep in mind when considering 
more purely institutional approaches to the rule of law, to which we now turn.

\section{THE CANONICAL INSTITUTIONAL FORMULATION}

For many economists and political scientists, the threat to the rule of law emanates from fundamental dilemmas in the nature of political power. The American federalists, and Madison in particular, were preoccupied with designing institutions to rein in the state. The idea of institutional checks and balances has been a staple of liberal and anarchist political theory ever since. Legal scholars have also associated the rule of law with restraints on the state: a government bound by law acts in conformity with statute, which in turn is changed only through established legislative means and not at the discretion or whim of the executive (Hayek 1978, Dicey 1982, Cass 2001).

The most important theoretical development for our purposes has been the joining of arguments about checks on state power to a consideration of the time inconsistency or credible commitment problem: the fact that governments not only have the power to renege on their commitments but can have powerful incentives to do so. Given these incentives, the rule of law cannot be credible, and the purported gains from property rights and enforcement of contract therefore cannot be fully realized, unless there are effective checks on executive discretion. Statements along these lines include the work of Buchanan (Buchanan \& Tullock 1962) and Hayek (1973) on constitutions, Root's (1994) work on the British and French monarchies, and Olson's (1993, McGuire \& Olson 1996) reflections on the economic dilemmas facing the predatory autocrat. Yet among the most influential statements in this vein are a succession of papers by Weingast, which we use as a touchstone for our discussion (North \& Weingast 1989; Weingast 1995, 1997; Schultz \& Weingast 2003).
Weingast (1997) argues that sovereigns can choose either to respect citizens' rights or to transgress them. However, in making this choice, the ruler faces two constraints. The first is economic.

The more likely it is that the sovereign will alter property rights for his or her own benefit, the lower the expected returns from investment and the lower in turn the incentive to invest. For economic growth to occur the sovereign or government must not merely establish the relevant set of rights, but must make a credible commitment to them.

Olson (1993, McGuire \& Olson 1996) attempts to show that this constraint alone can provide incentives for autocrats to exercise restraint and provide public goods, since the autocrat's own returns - in the form of taxeswill rise accordingly. Weingast (1997) introduces more realism to the spare Olsonian model, however, by noting that sovereigns also face political constraints on transgressing private rights, a problem Olson assumes away. Although citizens face coordination challenges, they can ultimately dispose of the sovereign; as a result, even autocrats make institutional, legal, and policy concessions to guard against this threat. North \& Weingast (1989) detail a variety of discrete institutional changes that constrained royal power in the wake of the Glorious Revolution, including the abolition of the Star Chamber and prerogatives surrounding it; the requirement that property rights cases be heard under common law; restrictions on monopoly; dismantling the royal administrative apparatus; and, most famously, the requirement that Parliament sit on a regular basis and exercise an effective veto on the raising of new revenues. Root (1994), North \& Weingast (1989), and Schultz \& Weingast (2003) find that these institutional changes lead to a variety of economic outcomes, affecting, for example, the state's capacity to borrow and investments associated with more secure property rights. 
The research program that has flowed out of this theoretical insight has looked to various forms of checks on government as a determinant of long-run growth. One formulation is that the existence of democracy is a necessary condition for the restraint of state power and the rule of law. For many years, the political science profession wrestled with the link between regime type and growth, and the results were inconclusive. Having conducted a sophisticated set of tests covering a very large sample of countries over the 1950-1990 period, Przeworski et al. (2000) claim to have laid the issue to rest:

- Controlling for income and other variables, regime type has no effect on investment, the growth rate of the capital stock, or overall income growth.

- There is no significant difference in the aggregate economic performance of wealthy dictatorships and wealthy democracies, but wealthy democracies exhibit somewhat slower growth in the capital stock, much slower growth in the labor force, and higher aggregate productivity growth.

- The standard deviation of growth among dictatorships is much larger than in the democracies (6.1 versus 3.9, controlling for several potentially confounding factors), confirming the important theoretical puzzle that the class of dictatorships includes both highgrowth "miracles" and low-growth "debacles."

Despite the conviction and finality with which Przeworski et al. report these findings, the research program surrounding democracy, the rule of law, and growth is by no means finished. Przeworski et al. do not probe the intervening political-institutional channels through which democracy operates on economic performance, for example, through property rights. Barro (1996) tests for the effects of democracy, controlling for property rights protection, and comes to similarly skep- tical conclusions; Barro even finds the effects of democracy to be mildly negative.

But a number of new approaches to testing the democracy-growth nexus have restored some of the indeterminacy that prevailed prePrzeworski et al. Gerring et al. (2005) argue that if democracy is treated as a stock rather than a level concept then longer history of continuous democratic rule does in fact have a positive effect on economic growth. Petrova \& Bates (2007) also find that the Przeworski et al. findings are not robust to an alternative specification of regime type that includes a third, intermediate type. Such semiauthoritarian or semidemocratic regimes - many transitional in nature-show greater economic volatility than either authoritarian or democratic regimes. Petrova \& Bates also find that democratic regimes have a significantly lower level of expropriation risk than fully autocratic ones.

An alternative empirical approach has been to look not at democracy per se but at the institutional checks on government that enhance the credibility of government commitments (Cox \& McCubbins 2001, Tsebelis 2002, MacIntyre 2003). These veto points can arise from basic constitutional arrangements (presidentialism, bicameralism), electoral rules (proportional representation and the corresponding likelihood of coalition governments) or other "horizontal" checks on government, such as independent central banks or regulatory agencies (Schedler et al. 1999). The most comprehensive effort to construct a database of such checks based on objective indicators rather than subjective evaluations has been undertaken by Henisz. He finds the expected relationship between checks and macroeconomic outcomes, such as overall economic growth (Henisz 2000a) and the volatility of policy (Henisz 2004), but also that checks are associated with higher levels of foreign direct investment (Henisz 2000b) and investment in infrastructure (Henisz 2002) and telecommunications (Henisz \& Zelner 2001; see also Stasavage 2002, 2003). 
The ideas that institutional restraints on state power are central to the very concept of the rule of law and that such checks constitute a key assurance for private actors are theoretically compelling. Nonetheless, many puzzles remain. Theory suggests that dictators cannot credibly commit to the protection of property rights because they always retain the discretion to renege on this commitment. Yet a number of dictatorships have overseen dynamic private sector growth. How?

Several possibilities suggest themselves for future exploration. First, the stability and duration of political systems and the associated time horizons of leaders may be as significant as formal checks on government. We have ample empirical evidence of the adverse effects of government instability on economic performance (Alesina et al. 1996). This solution may not be theoretically satisfying, but sheer stability and duration may serve to stabilize investor expectations.

Alternatively, challenges to authoritarian rule may keep rulers honest. As Weingast (1997) admits, and as Bueno de Mesquita et al. (2003) and Acemoglu \& Johnson (2005) emphasize even more forcefully, it is not the formal institutions that constitute the true check on executive discretion. Rather it is the threat of being deposed. Such threats-including the external ones facing authoritarian leaders in Korea and Taiwan-may invite or even force compromises with private sector actors.

Finally, we need to look beyond institutions to the underlying configuration of interests on which they rest. In an important critique of North \& Weingast (1989), Stasavage $(2002,2003)$ argues that it is not the institutional checks that matter for executive restraint-even in the canonical English case-but the extent to which the executive's own support base would be harmed by an adverse shift in policy. Parliament acted as a check on the king because it directly represented the bondholders in the political process. Broz \& Weymouth (2007) find that the partisan orientation of government is a powerful predictor of business percep- tions of property rights security. Using microlevel data, they find that respondents feel more secure when conservative governments are in power. When controlling for partisanship, they find that institutional checks have little effect in this regard. Such fundamentally coalitional approaches also provide another avenue for understanding the East Asian anomalies. Right-wing governments allied to the private sector constituted the political foundations for growth despite apparently adverse institutional arrangements and weak rule of law. Recognition of the importance of the configuration of interests underpinning particular institutions should encourage caution in policy practitioners seeking to promote institutional change in other countries.

\section{LEGAL SYSTEMS, COURTS, AND JUDICIARIES}

The themes addressed in the two previous sections-the threats to economic activity emanating from both private corruption and executive discretion-are replicated when we consider the judiciary and features of the legal system more narrowly conceived (for a formal model along these lines, see Glaeser \& Schleifer 2002). An obvious but nonetheless complex challenge for developing countries is the lack of resources. Poor countries do not have the trained personnel nor financial wherewithal to maintain effective judicial systems (e.g., Buscaglia 1998). ${ }^{6}$ However, it does not follow that more resources are likely to overcome the legal barriers to economic

\footnotetext{
${ }^{6} \mathrm{~A}$ lack of resources has a myriad of consequences. Courts face overwhelming caseloads, which lead to delays and distortions in the processing of cases. These weaknesses in turn have a deterrent effect on the use of the courts (Buscaglia 1998, Buscaglia \& Ulen 1995). A lack of resources also threatens the integrity of courts, independently of the issue of outright corruption. Without resources, courts cannot provide poor and unsophisticated individuals with information about the court system or legal assistance; access is correspondingly limited and judicial outcomes will favor wealthy and savvy insiders over other claimants. Resource scarcity also has an effect on corruption, as underpaid judges and legal staff turn to bribery and extortion to supplement their incomes.
} 
development where deeper political constraints operate. Indeed, lack of funding might itself be the result of political choices to limit judicial independence. We begin our discussion of judicial and legal systems with a consideration of judicial independence before considering the complex body of work on the significance of legal origins, and the difference between common and civil law traditions in particular.

\section{Judicial Independence}

When legal scholars talk about the rule of law, the independence of the judiciary often features as a prominent determinant of the quality of justice courts dispense (e.g., Prillaman 2000). The institutional correlates of independence are by no means clear, however. One strand in the judicial independence literature looks at institutionalized political control over the judiciary. Most legal scholars believe that appointment of judges is more likely to guarantee independence than election, which requires a campaign for votes, organized interest group support, and campaign contributions (e.g., Hanssen 1999). However, appointment of judges by legislators can result in highly politicized judiciaries, compared, for example, to systems in which civil society actors play a role (Moreno et al. 2003). Institutional constraints on judicial independence can also arise from limits on the length of judicial appointment, ${ }^{7}$ or a lack of control over judicial administration (Russell 2001), budget (Domingo 2000), and discipline (Hanssen 1999). Independence is reduced when the judiciary is deprived of significant constitutional powers, such as the power of judicial review

\footnotetext{
${ }^{7}$ For example, Moreno et al. (2003) propose a "term ratio" to analyze variations in tenure, "which is the ratio of the official's term to the term of the elected branch that is involved in the appointment" (p. 103). Low term ratios indicate lack of independence, as elected officials can easily remove sitting judges; higher term ratios signal more independence, and not coincidentally the possibility of forging a longer-term career as a judge.
}

(see Ginsburg 2003 on Asia; see Hammergren 2007, pp. 180-97, on Latin America).

Judicial independence may also suffer from direct political manipulation. For example, Ramseyer (1994) and Ramseyer \& Rasmussen (2001) show how Japanese politicians manipulate sitting judges' career paths, including by assignment to undesirable locations and tasks. Conversely, studies of Argentina, a country traditionally considered lacking in judicial independence, show that judges exhibited more gumption in taking on the government when its prospects for survival dimmed (Helmke 2002) or when discretion over judicial appointments decreased (Iaryczower et al. 2002) A third strand of literature on judicial independence argues that independence is not a constant feature of a given legal and judicial system but "waxes and wanes with changes in the political composition of [the] three branches of government" (McNollgast 2006). Judicial independence is greater, for example, under divided government than under unified government, which permits the executive and legislature to coordinate to undermine judicial decisions, pack the courts, or increase the number of courts with loyal agents. Judicial independence also may vary depending on the policy issue being discussed (Tiede 2006). In certain areas, such as property rights enforcement, the legislature may curtail judicial discretion, while in other areas, they will allow the judiciary more discretion. In this way, judicial independence fluctuates not only with political alignments but also with policy saliency.

As with other areas we have described, there is an emerging literature on the effects of judicial independence on economic policy and performance. La Porta et al. (2004) code judicial independence using objective indicators such as judicial tenure and the law-making power of judicial decisions, and they find that independence has positive effects on the security of property rights, among other regulatory outcomes. Interestingly, however, an overlapping team (Glaeser \& Shleifer 2002) does not find that judicial independence is 
associated with long-run growth. An impressive effort by Feld \& Voigt (2003) offers at least one possible explanation for these divergent findings. They construct a new database on both de jure and de facto judicial independence, each an index of multiple component parts, focusing on the highest court in each country. Their de jure measures cover several of the formal institutional features noted above; the de facto measures cover actual outcomes, such as the effective length of terms and trends in budgets. They find that whereas GDP growth (1980-1998) is not affected by de jure independence, it is affected by de facto independence. Institutions may matter, but "real" rather than formal ones should be our target.

To date, these studies have focused on high or supreme courts, and thus are really addressing the larger constitutional issue of checks and balances on government discussed in the previous section. They do not address the question of the independence of the lower courts that handle most routine property and contract claims. However, the claim that judicial independence is a necessary condition for the protection of property rights or economic growth should give any American political scientist pause. As Ferejohn (1999, p. 355) points out, the American federal judiciary "is institutionally dependent on Congress and the president for jurisdiction, rules, and execution of judicial orders." In a biting critique of what he calls the "rule of law orthodoxy," Upham (2006, p. 85) notes not only that the American judiciary is subordinate in this formal institutional sense, but that American judges are appointed by politicians or are elected, and "overwhelmingly follow their political preferences when the opportunity presents itself." These facts notwithstanding, the United States has obviously enjoyed high growth over the long run, as has Japan, which arguably has an even more constrained judiciary. Upham contends that this outcome probably rests on some underlying features of the political system, such as the lack of polarization across the parties, rather than any formal institutional features of the system itself. This theme arises in the debate over the economic consequences of different legal systems as well.

\section{Legal Origins}

Perhaps the most dynamic body of research on the link between the rule of law and economic development has grown out of a series of important papers by La Porta et al. (1997, $1998,1999,2000,2002,2004)$ and their colleagues (Glaeser \& Shleifer 2002; Djankov et al. 2002, 2003) on legal origins. This literature is now so substantial that it has already generated several reviews - and numerous critiques_of its own (Beck et al. 2001, Demirgüç-Kunt \& Levine 2001, Gourevitch 2003, Roe 2006, Dam 2006, Keefer 2007).

The starting point for this literature is the presumption that property rights and support of private contractual arrangements are conducive to growth. But this body of work places particular emphasis on finance-one of the first legal origins papers was entitled simply "Law and Finance" (La Porta et al. 1998)_ and as a result opens the door on a host of issues: the organization of the firm; the significance of company, bankruptcy, and security laws; corporate governance; and the evolution of financial systems. An early finding, for example, was that countries that protect the legal rights of minority shareholders have a higher level of external finance for companies (at the micro level) and deeper overall financial development (at the macro level). Financial development, in turn, is a well-documented determinant of long-run growth, thus providing an alternative causal channel from the legal system to growth.

The more controversial component of the law and finance approach is the claim that the different legal traditions that emerged in Europe over previous centuries, and were subsequently spread through conquest, colonization, and imitation, help explain cross-country variation in the strength of property rights protection and the enforcement of contract. In particular, La Porta et al. emphasize the 
distinction between common and civil law traditions, and within the latter between Scandinavian, German, and French legal traditions. Common and civil law traditions vary in their deference to the state, the respect they show toward private property, and the corresponding strength and independence of enforcement of private claims. Civil law systems are less hospitable to private economic activity than are common law systems, with the French legal tradition having particularly deleterious effects compared with the German or Scandinavian civil law models. These differences are visible both in statute and in the role of the state more generally. La Porta et al. (1999) find, for example, that state-owned enterprises play a greater role in legal systems with a French heritage than in common law countries. Civil law countries have more government ownership of banks (La Porta et al. 2002). Djankov et al. (2002) find that (French) civil law countries regulate entry more heavily than common law countries, and Botero et al.'s (2004) study on labor markets in 85 countries finds more restrictive labor law-at least from the perspective of business-in (French) civil law than in common law cases.

Beyond statute, these differences extend to the operation of institutions. La Porta et al. (2004) find that civil law countries are less likely to grant judges tenure, give courts jurisdiction over cases involving the government, or permit judicial review of the constitutionality of laws. However, the core theoretical argument is that legal systems differ in their procedural formalism, adaptability to changing circumstances, and therefore efficiency. Formalism introduces a variety of transaction costs that affect the efficiency (although not necessarily the quality) of justice. For example, Djankov et al. (2003) consider features of legal systems that might slow judgment on two discrete actions: evicting a tenant (a proxy for property rights) and collecting on a bounced check (a proxy for contract enforcement). These features include the required degree of professionalism, demands for writ- ten versus oral presentation, and procedural requirements.

According to the legal origins approach, formalism and reliance on statute also have wider consequences for the law. Civil law countries tie the hands of judges and are less flexible and adaptable to changing circumstance. Governments with civil law systems can adapt to changing circumstances only by revising statute, which is supposed to be slower and more costly. Common law systems, by contrast, evolve through continual litigation and relitigation, which improves the efficiency of the law.

With the possible exception of the claims about the relationship between financial development and growth, few components of the La Porta et al. corpus have gone unchallenged. There has been disagreement over the assignment of countries to particular legal families (Dam 2006, pp. 36-55; Siems 2006), over the coding of the legal protections on which they are presumed to vary (Dam 2006, pp. 169-77), and even on such basic questions as whether the laws coded are germane to the theory. Is the legal origins model primarily about variation in private law-particularly corporate and commercial law-as the early formulations suggest (e.g., La Porta et al. 1998)? Or do the core claims really pertain to public law and issues such as the checks on government or credible enforcement?

Yet these problems arise in any such research program, and this one is hardly static; subsequent iterations have expanded the coverage of countries and created fascinating new data sets (see particularly Djankov et al. 2003). However, there are serious questions about the surface plausibility of the claimed effects of legal origins on development, particularly with respect to poorer countries. In a review of the relationship between legal origins and his own extensive data set on governance indicators, Kaufmann (2003b) notes that there is some correlation in the total data set of 200 countries between legal origins and his governance indicators. However, when Kaufmann considers the poorest 75 countries-those in 
which the challenges to governance and effective rule of law are the most pronouncedthese differences virtually disappear. Common law countries perform marginally better on three components of his governance index (accountability, rule of law, and government effectiveness), even with civil law countries on a fourth (regulatory quality), and not as well as civil law countries with respect to political stability and control of corruption. Moreover, there is substantial variation among developing countries within each category. Chile and Iraq are both civil law countries; Ireland and Sierra Leone common law countries. Yet does anyone believe that the performance of Sierra Leone or Iraq is likely to be explained to any significant degree by its legal system, however defined?

Nonetheless, it is plausible that at a certain stage of development-say, among middleincome countries-the nature of the law with respect to equity markets, corporate governance, and the financial sector are consequential for sustained growth. These issues have been brought home with great force in the wake of the financial crises of the 1980s and 1990s, in which regulatory failures were identified as culprits. Yet once again, basic methodological issues pose challenges to the legal origins approach. As with other strands of the long-run growth literature, the legal origins approach presumes that early (and largely unexplained) institutional choices cast long shadows: Legal family is fate. Yet as Rajan \& Zingales $(2003,2004)$ point out in an influential critique, the paradigmatic cases shift course. France had substantially deeper financial markets than the United States in 1913. These positions had reversed by 1980 , but were converging by the late 1990s. More generally, the advanced industrial states had converged on roughly similar levels of income per capita despite divergent legal systems, suggesting that different "varieties of capitalism" were compatible with long-run growth.

Of particular interest to political scientists are challenges to the legal origins school that have focused on the political determinants of corporate governance. Among the candidates explored have been the power of financial incumbents (Rajan \& Zingales 2004), partisanship (Roe 2003), and variations in the political alignments between labor and capital (Gourevitch \& Shinn 2005; see Gourevitch 2003 for a review). These studies all underline the simple point that the regulatory environment facing business is not static within legal families but is subject to change depending on political circumstance. There is great promise in applying these explanations for the varieties of capitalism among the advanced industrial states to the puzzle of the diverse growth strategies visible across the middleincome developing countries of Asia, Latin America, and the postsocialist world.

\section{LAWLESSNESS AND INFORMAL INSTITUTIONS}

The bulk of our discussion thus far has emphasized formal political and legal institutions: government enforcement of property rights and contract; institutional checks on corrupt private actors and public officials; independent judiciaries; and well-functioning courts. However, as Dixit (2004, p. 3) puts it,

only advanced countries in recent times come anywhere near the economist's ideal picture, in which the government supplies legal institutions that are guided solely by concern for social welfare and operate at low cost. In all countries through much of their history, the apparatus of state law was very costly, slow, unreliable, biased, corrupt, weak, or simply absent. In most countries this situation still prevails.

Yet nothing in the property rights and contracting literature-our theoretical touchstone-suggests that formal institutions are either necessary or sufficient for security of property rights and contract enforcement. Can informal institutions serve as a substitute for the more formal institutions that we review here? Or are such mechanisms simply a 
second-best adaptation to the absence of formal institutions?

One strand of work in this area has been the historical examination of the institutions surrounding long-distance trade in the Mediterranean world and early modern Europe. Greif $(1993,1997)$ showed how Mahgribi and Genoese traders overcame their vulnerability to distant agents through the formation of coalitions that could exclude them from the benefits of future trade. In a similar vein, Milgrom et al. (1990) show how private merchant courts in the Champagne fairs provided contract enforcement, in part through centralized record-keeping that enabled the identification and exclusion of merchants who had breached agreements. Greif et al. (1994) expand on this argument to show how merchant guilds in many parts of medieval Europe resolved both contract enforcement problems for merchants and commitment problems for local rulers.

Contemporary studies also find ample evidence of informal solutions to contract enforcement problems in the absence of formal legal institutions. Several Asian examples make the point and again provide insight into the success of market-oriented reforms in authoritarian systems. Survey work in Vietnam (McMillan \& Woodruff 1999) reveals how social and business networks provide information about the reputation of partners ex ante and assist in contract enforcement ex post. Tsai's (2002) major study of "back-alley banking" documents a range of informal mechanisms for enforcing loan contracts, from trustbased relationship lending through more institutionalized mechanisms such as credit cooperatives.

Rauch (2001) reviews the theory and evidence about ethnic, religious, and linguistic networks and shows that these institutions remain relevant to long-distance commerce and international trade. The existence of a moral bond within a particular community and the threat of collective punishment by other members of the community has facilitated trade on the part of the widely scattered Chinese diaspora in the Asia Pacific.

All of these examples go beyond simple relationship-based business among agents with long histories of working together or the elusive characteristic called trust. Key to the success of these self-governing informal frameworks are three core elements: the dependence of traders on reputation; the capacity of informal institutions to provide and relay information on transgressions among the network of participants; and the existence of a fully incentive-compatible and decentralized sanctions mechanism in the simple form of the refusal to deal.

But are these institutions sufficiently efficient and robust to constitute an alternative path for growth? Or are they ultimately transitional? In his masterful and sympathetic review, Dixit (2004) identifies cogent theoretical reasons for believing that there are limits to the durability of these self-governing frameworks. Scale is key. As the number of participants increases, it becomes increasingly difficult to maintain information flows to warn of transgressions and punishment mechanisms to sanction offenders. In effect, the more efficient a self-governing framework is, the more participants it is likely to attract, which in turn degrades its effectiveness. Yet in the absence of functioning courts-which may be subject to the various other constraints we have identified-such institutions may be more worthy of support than costly rule-oflaw programs that are unlikely to function as anticipated (Carothers 2006). Support for business associations that can sanction their members may be more effective in ensuring contract than rebuilding dysfunctional courts.

\section{CONCLUSION}

We have sought to provide an overview of the literature on the relationship between the rule of law and economic development. Our most basic point is that the term rule of law is used in a plethora of ways, often with different and even contradictory implications for both 
research (see Appendix) and policy. For example, if the rule of law is taken to mean the provision of security, then many developing countries face the basic problem of developing adequate state capacity. Yet in other settings, states dominate and squeeze out private activity or fail to provide credible assurances to private agents; in these settings, institutional and political checks on government are required.

But the problem is not merely a terminological one, to be resolved by clarifying usage. We have also underlined the problem of the complementarity, if not endogeneity, of the variety of institutions that make up "the rule-of-law complex." The foundational logic of the new institutional economics strikes us as compelling: Investment, trade, financial development, and growth will suffer without relative security of property and contracting and incentives against private appropriation of corporate assets. Yet property rights and the integrity of contract are not simply the result of "getting the law right" in any narrow sense. Rather, property rights come out of a complex causal chain that includes a variety of complementary institutions and political bargains-with respect to security, appropriate checks on private capture of the state, institutional checks on state power, and the more discrete features of the judicial and legal system. In simplest form: Property rights and contracting rest upon institutions, but these in turn rest upon deep coalitions of consenting interests.

Three cautionary notes flow from our arguments. First, notwithstanding the passion of the development policy community for spreading judicial best practice, caution should be exercised in the introduction of an alien legal system. As Upham (2006, pp. 7576) emphasizes, it is a grave error to think of law as a technology that can be readily transferred elsewhere. Rather than a movable technical apparatus, law is a set of institutions deeply embedded in particular political, economic, and social settings. Borrowing and learning from the institutional arrange- ments of other countries take place and in some instances have good effects, but institutions do not necessarily have the same effects when transplanted from one context to another. To redeploy the memorable line of former Brazilian minister Luis Carlos Bresser Pereira, "institutions can at most be imported, never exported" (quoted in Przeworski 2004, p. 540). Quite apart from the inherent difficulties in implementing serious reform of legal institutions, it is to misunderstand development to place high hopes and expectations on what any one ingredient-even one as fundamental as this_-can accomplish.

Second, it is very probable that a strong formal legal system, underwritten by a set of political checks on state power and corruption, is the most efficient solution to the problem of insecurity of property and contracting in a modern economy. Yet for countries at low levels of development, the types of informal institutions that generated trade in early modern Europe may be more relevant than the complex statute and demanding institutions of the American or current European legal systems. Informal solutions to corruption problems or to contracting problems may be suboptimal when compared to a hypothetical alternative, but still an improvement on the the status quo.

This review has taken a highly instrumental view of the rule of law, stressing its utility for growth in particular. But our final and most important point is that the rule of law is of great importance as a value in its own right and as a contributor to other values, such as human freedom. Yet precisely for that reason-because we believe in the rule of law-it is all the more important that those who would offer development assistance make sure, first, to do no harm.

\section{APPENDIX: RULE-OF-LAW INDICATORS}

This appendix provides an overview of some widely used indicators of the rule of law. The rule of law is measured as security of property; 
as security of person; and as captured by the independence and effectiveness of the judiciary. In each case, we provide an example of recent scholarly work that has used the indicators in question. We also include some selective measures of cognate concepts, such as corruption, and of complementary features of the political environment that are held to influence the rule of law, such as checks on government and democracy. We compare these more discrete variables with one of the most prominent overall rule-of-law indices from the World Bank's Worldwide Governance Indicators (1996 to 2006).

The survey is not intended to be exhaustive. Tiede (2007) provides a more thorough overview of $\sim 30$ rule-of-law indicators and the relationships among them, as well as a robustness test on Djankov et al. (2003) designed to show the sensitivity of that analysis to alternative specifications. Rather, this appendix is designed as a cautionary tale, suggesting the problems of construct validity and measurement error that can arise in cross-national quantitative research in this field.

We provide an overview of each category of indicators by describing the existing measurements and methodology, and a summary of how each indicator is correlated with similar indicators within each conceptual category. For consistency we compare indicators for a single year, 2004; when this year is not available, we choose the closest year and indicate the year chosen. At the end of the appendix, we summarize between-category correlations. Where web sites are cited, the date of access is September 19, 2007.

One of the striking features of this exercise is the relatively low level of correlation both within and across categories. In some cases, particularly with the indicators coming out of the legal origins literature, the variables in question are negatively correlated with other rule-of-law indicators. Significantly, some of the more widely discussed variables in the literature (checks, democracy, rule of law, and legal formalism) are barely correlated to more discrete rule-of-law indicators for property, security, judicial independence, and court efficiency. Corruption is highly correlated to our separate and aggregate rule-of-law indicators, but not to checks, democracy, or legal formalism. Although correlation does not equal causation, these results suggest the need for further research on the complex channels through which these institutions are presumed to operate, for example, from checks and balances to property rights, or from judicial independence to corruption. They also suggest the particular importance of robustness checks when one is making claims about the effects of the rule of law. 
Table 1 Security of property (correlation between the two measures: 0.83 )

\begin{tabular}{|c|c|c|}
\hline Existing measurement & Description of method & Scholarly examples \\
\hline \multirow[t]{4}{*}{$\begin{array}{l}\text { Heritage Foundation/ } \\
\text { Wall Street Journal } \\
\text { property }\end{array}$} & $\begin{array}{l}\text { Assesses "the degree to which a country's laws protect private } \\
\text { property rights and the degree to which its government enforces } \\
\text { those laws. It also assesses the likelihood that private property will be } \\
\text { expropriated and analyzes the independence of the judiciary, the } \\
\text { existence of corruption within the judiciary, and the ability of } \\
\text { individuals and businesses to enforce contracts." }\end{array}$ & \multirow[t]{4}{*}{$\begin{array}{l}\text { La Porta et al. (1999), } \\
\text { Djankov et al. (2003), } \\
\text { Acemoglu \& Johnson } \\
(2005)\end{array}$} \\
\hline & Approximately 156 countries: 1996 to present & \\
\hline & Objective assessment and subjective ratings based on checklist & \\
\hline & Source: http://www.heritage.org/index/ & \\
\hline \multirow[t]{4}{*}{$\begin{array}{l}\text { World Economic } \\
\text { Forum property }\end{array}$} & $\begin{array}{l}\text { Assesses the extent to which financial assets and wealth are protected } \\
\text { by law }\end{array}$ & \multirow[t]{4}{*}{$\begin{array}{l}\text { One source of data for } \\
\text { Worldwide Governance VI } \\
\text { rule-of-law measurement }\end{array}$} \\
\hline & $\begin{array}{l}\text { Approximately } 104 \text { countries: 1996, 1998, 2000, 2002, 2004, } \\
2005-2007\end{array}$ & \\
\hline & Survey of business executives & \\
\hline & Source: http://www.weforum.org/ & \\
\hline
\end{tabular}

Table 2 Security of person (correlation between the two measures: 0.60 )

\begin{tabular}{|c|c|c|}
\hline Existing measurement & Description of method & Scholarly examples \\
\hline \multirow[t]{4}{*}{$\begin{array}{l}\text { World Economic } \\
\text { Forum crime and } \\
\text { violence }\end{array}$} & $\begin{array}{l}\text { Assesses the extent to which common crime and violence (e.g., street } \\
\text { muggings, firms being looted) impose significant cost to business }\end{array}$ & \multirow[t]{4}{*}{$\begin{array}{l}\text { One source of data for } \\
\text { Worldwide Governance VI } \\
\text { rule-of-law measurement }\end{array}$} \\
\hline & $\begin{array}{l}\text { Approximately } 104 \text { countries: } 1996,1998,2000,2002,2004, \\
2005-2007\end{array}$ & \\
\hline & Survey of business executives & \\
\hline & Source: http://www.weforum.org/ & \\
\hline \multirow[t]{4}{*}{$\begin{array}{l}\text { Worldwide Governance } \\
\text { VI political stability } \\
\text { and absence of } \\
\text { violence }\end{array}$} & $\begin{array}{l}\text { Aggregate measure of a variety of sources "measuring perceptions of } \\
\text { the likelihoood that the government will be destabilized or } \\
\text { overthrown by unconstitutional or violent means, including } \\
\text { domestic violence and terrorism" }\end{array}$ & \multirow[t]{4}{*}{$\begin{array}{l}\text { One of six dimensions of } \\
\text { Worldwide Governance } \\
\text { VI's overall governance } \\
\text { measurement }\end{array}$} \\
\hline & 212 countries; $1996-2006$ & \\
\hline & Survey, subjective and objective assessments & \\
\hline & Source: http://info.worldbank.org/governance/wgi2007/ & \\
\hline
\end{tabular}


Table 3 Independent judiciary (correlation between the two measures: 0.15 )

\begin{tabular}{|c|c|c|}
\hline Existing measurement & Description of method & Scholarly examples \\
\hline \multirow[t]{4}{*}{$\begin{array}{l}\text { World Economic } \\
\text { Forum judicial } \\
\text { independence }\end{array}$} & $\begin{array}{l}\text { Assesses the extent to which the judiciary is independent and not } \\
\text { subject to interference by the government and/or parties to the } \\
\text { dispute }\end{array}$ & \multirow[t]{4}{*}{$\begin{array}{l}\text { One source of data for } \\
\text { Worldwide Governance VI } \\
\text { rule-of-law measurement }\end{array}$} \\
\hline & $\begin{array}{l}\text { Approximately } 104 \text { countries: 1996, 1998, 2000, 2002, 2004, } \\
2005-2007\end{array}$ & \\
\hline & Survey of business executives & \\
\hline & Source: http://www.weforum.org/ & \\
\hline \multirow[t]{4}{*}{$\begin{array}{l}\text { Judicial Independence } \\
\text { index }\end{array}$} & $\begin{array}{l}\text { Objective index computed as the normalized sum of }(a) \text { the tenure of } \\
\text { Supreme Court judges; }(b) \text { the tenure of administrative court judges; } \\
\text { and }(c) \text { the case law variable, which measures whether judicial } \\
\text { decisions in a given country constitute case law }\end{array}$ & \multirow[t]{4}{*}{$\begin{array}{l}\text { La Porta et al. (2004), } \\
\text { Glaeser et al. (2004) }\end{array}$} \\
\hline & $\begin{array}{l}72 \text { countries: various years, but index is based on sources predating } \\
2004\end{array}$ & \\
\hline & Objective assessment & \\
\hline & $\begin{array}{l}\text { Data were taken from La Porta, Rafael website, http://mba.tuck. } \\
\text { dartmouth.edu/pages/faculty/rafael.laporta/publications.html, } \\
\text { for the article "Judicial Checks and Balances" (2004) }\end{array}$ & \\
\hline
\end{tabular}

Table 4 Court effectiveness/function (correlation between the two measures: 0.64)

\begin{tabular}{|c|c|c|}
\hline Existing measurement & Description of method & Scholarly examples \\
\hline \multirow[t]{4}{*}{$\begin{array}{l}\text { Political Risk Services } \\
\text { International Country Risk } \\
\text { Guide (ICRG) law and order }\end{array}$} & $\begin{array}{l}\text { The } 2000 \text { index assesses the strength and impartiality of the } \\
\text { legal system; the order subcomponent assesses popular } \\
\text { observance of the law }\end{array}$ & \multirow[t]{4}{*}{$\begin{array}{l}\text { La Porta et al. (1998), } \\
\text { Djankov et al. (2003) }\end{array}$} \\
\hline & 140 countries: 1996, 1998, 2000, 2002, 2004, 2006 & \\
\hline & Subjective analysis of available information to create risk rating & \\
\hline & Source: http://www.prsgroup.com/ & \\
\hline \multirow[t]{4}{*}{$\begin{array}{l}\text { World Economic Forum } \\
\text { efficiency }\end{array}$} & $\begin{array}{l}\text { Assesses the extent to which the legal framework for private } \\
\text { businesses can settle disputes and challenge the legality of } \\
\text { government actions and/or regulations }\end{array}$ & \multirow[t]{4}{*}{$\begin{array}{l}\text { One component of } \\
\text { Worldwide Governance } \\
\text { VI rule-of-law index }\end{array}$} \\
\hline & $\begin{array}{l}\text { Approximately } 104 \text { countries: } 1996,1998,2000,2002,2004 \text {, } \\
2005-2007\end{array}$ & \\
\hline & Survey of business executives & \\
\hline & Source: http://www.weforum.org/ & \\
\hline
\end{tabular}


Table 5 Contextual variables

\begin{tabular}{|c|c|c|}
\hline Existing measurement & Description of method & Scholarly examples \\
\hline \multirow{4}{*}{$\begin{array}{l}\text { Transparency } \\
\text { International } \\
\text { corruption perception }\end{array}$} & Assesses the overall extent of corruption & \multirow{4}{*}{$\begin{array}{l}\text { Treisman (2000), Djankov } \\
\text { et al. (2003) }\end{array}$} \\
\hline & Approximately 150 countries: 1995-2007 & \\
\hline & Surveys of both businessmen and country analysts & \\
\hline & $\begin{array}{l}\text { Source: http://www.transparency.org/policy_research/ } \\
\text { surveys_indices/cpi }\end{array}$ & \\
\hline \multirow[t]{4}{*}{$\begin{array}{l}\text { Polity IV constraints on } \\
\text { executive }\end{array}$} & $\begin{array}{l}\text { This variable refers to the "extent of institutionalized } \\
\text { constraints on decision-making powers of chief executives, } \\
\text { whether individuals or collectivities. Such limitations may be } \\
\text { imposed by any 'accountability groups'. In Western } \\
\text { democracies these are usually legislatures. Other kinds of } \\
\text { accountability groups are the ruling party in a one party state; } \\
\text { councils of nobles or powerful advisors in monarchies; the } \\
\text { military in coup-prone polities; and in many states a strong } \\
\text { independent judiciary. The concern is therefore with the } \\
\text { checks and balances between the various parts of the } \\
\text { decision-making process" (Polity IV Manual) }\end{array}$ & \multirow[t]{4}{*}{$\begin{array}{l}\text { Glaeser et al. (2004), } \\
\text { Acemoglu \& Johnson (2005) }\end{array}$} \\
\hline & Country coverage varies by years: $1800-2004$ & \\
\hline & Subjective and objective criteria using ranking system & \\
\hline & Source: http://www.cidcm.umd.edu/polity/ & \\
\hline \multirow[t]{4}{*}{ Polity IV democracy } & Widely used democracy variable & \multirow{4}{*}{$\begin{array}{l}\text { Glaeser et al. (2004), } \\
\text { Acemoglu \& Johnson (2005) }\end{array}$} \\
\hline & Country coverage varies by years: $1800-2004$ & \\
\hline & $\begin{array}{l}\text { Subjective and objective assessment using ranking system by } \\
\text { experts }\end{array}$ & \\
\hline & Source: http://www.cidcm.umd.edu/polity/ & \\
\hline \multirow[t]{5}{*}{ Bertelsmann rule of law } & $\begin{array}{l}\text { General rule-of-law index based on civil liberties and checks } \\
\text { and balances on government }\end{array}$ & \multirow{5}{*}{$\begin{array}{l}\text { One source of data for } \\
\text { governance VI rule-of-law } \\
\text { measurement }\end{array}$} \\
\hline & $\begin{array}{l}\text { Discrete components include: }(a) \text { Does the separation of } \\
\text { powers (checks and balances) work? }(b) \text { Does an independent } \\
\text { judiciary exist? }(c) \text { Are there legal or political penalties for } \\
\text { officeholders who abuse their position? }(d) \text { To what extent are } \\
\text { civil liberties guaranteed and to what extent can citizens seek } \\
\text { redress for violations of these liberties? }\end{array}$ & \\
\hline & 116 countries: $2002,2004,2006$ & \\
\hline & Subjective assessment of detailed reports from experts & \\
\hline & $\begin{array}{l}\text { Source: http://www.bertelsmann-transformation-index.de/ } \\
\text { 16.0.html? \&L=1 }\end{array}$ & \\
\hline \multirow[t]{4}{*}{$\begin{array}{l}\text { Worldwide Governance } \\
\text { VI rule of law }\end{array}$} & $\begin{array}{l}\text { Aggregate measure of a variety of sources "measuring the } \\
\text { extent to which agents have confidence in and abide by the } \\
\text { rules of society, and in particular the quality of contract } \\
\text { enforcement, the police, and the courts, as well as the } \\
\text { likelihood of crime and violence" }\end{array}$ & \multirow[t]{4}{*}{$\begin{array}{l}\text { Easterly \& Levine (2003); } \\
\text { one of six dimensions of } \\
\text { Worldwide Governance VI's } \\
\text { overall governance } \\
\text { measurement }\end{array}$} \\
\hline & 212 countries: $1996-2006$ & \\
\hline & Surveys, objective and subjective assessment & \\
\hline & Source: http://info.worldbank.org/governance/wgi2007/ & \\
\hline
\end{tabular}


Table 5 (Continued)

\begin{tabular}{|c|c|c|}
\hline Existing measurement & Description of method & Scholarly examples \\
\hline \multirow[t]{4}{*}{$\begin{array}{l}\text { Legal formalism: tenant } \\
\text { eviction, check } \\
\text { collection }\end{array}$} & $\begin{array}{l}\text { Two aggregate indices of seven aspects of formalism, defined as } \\
\text { "the extent to which regulation causes dispute resolution to } \\
\text { deviate from the neighbor model"* (Djankov et al. 2003, } \\
\text { p. 456) }\end{array}$ & \multirow[t]{4}{*}{$\begin{array}{l}\text { Acemoglu \& Johnson } \\
\text { (2005) using expanded } \\
\text { version of Djankov et al. } \\
\text { (2003) from World Bank }\end{array}$} \\
\hline & 109 countries & \\
\hline & $\begin{array}{l}\text { Surveys of law firms, and laws of each country and other } \\
\text { aggregate indices }\end{array}$ & \\
\hline & $\begin{array}{l}\text { Data were taken from La Porta, Rafael website, } \\
\text { http://mba.tuck.dartmouth.edu/pages/faculty/rafael.laporta/ } \\
\text { publications.html, for the article "Courts" (2003) }\end{array}$ & \\
\hline
\end{tabular}

\footnotetext{
*The neighbor model refers to Shapiro's (1981) idealized court in which two neighbors have a third party resolve their dispute on the basis of fairness alone, without written evidence, procedural constraints, or argument. See Djankov et al.'s (2003, p. 455) categorization of Shapiro (1981).
}

Table 6 Ranges of correlation between rule-of-law categories

\begin{tabular}{l|c|c|c|c}
\hline $\begin{array}{l}\text { Indicator (within-category } \\
\text { correlation) }\end{array}$ & $\begin{array}{c}\text { Property } \\
\mathbf{( 0 . 8 3 )}\end{array}$ & $\begin{array}{c}\text { Security } \\
(\mathbf{0 . 6 0}\end{array}$ & $\begin{array}{c}\text { Independent judiciary } \\
(\mathbf{0 . 1 5})\end{array}$ & $\begin{array}{c}\text { Court efficiency } \\
(\mathbf{0 . 6 4 )}\end{array}$ \\
\hline Property & & 0.20 to 0.73 & 0.12 to 0.89 & 0.58 to 0.89 \\
\hline Security & 0.20 to 0.73 & & 0.00 to 0.75 & 0.60 to 0.67 \\
\hline Independent judiciary & 0.12 to 0.89 & 0.00 to 0.75 & & -0.04 to 0.91 \\
\hline Court efficiency & 0.58 to 0.89 & 0.60 to 0.67 & -0.04 to 0.91 & \\
\hline
\end{tabular}

Table 7 Ranges of correlation between rule of law and contextual variables

\begin{tabular}{l|c|c|c|c|c|c}
\hline $\begin{array}{l}\text { Indicator } \\
\text { (within- } \\
\text { category } \\
\text { correlation) }\end{array}$ & $\begin{array}{c}\text { Checks } \\
\text { (Polity IV) }\end{array}$ & $\begin{array}{c}\text { Corruption } \\
\text { (Transparency } \\
\text { International) }\end{array}$ & $\begin{array}{c}\text { Democracy } \\
\text { (Polity IV) }\end{array}$ & $\begin{array}{c}\text { Rule of law } \\
\text { (Worldwide } \\
\text { Governance VI) }\end{array}$ & $\begin{array}{c}\text { Legal } \\
\text { formalism: } \\
\text { tenant } \\
\text { eviction } \\
\text { (Djankov } \\
\text { et al. } 2003 \text { ) }\end{array}$ & $\begin{array}{c}\text { Legal } \\
\text { formalism: } \\
\text { check } \\
\text { collection } \\
\text { (Djankov } \\
\text { et al. 2003) }\end{array}$ \\
\hline $\begin{array}{l}\text { Property (0.83) } \\
\text { Security (0.60) }\end{array}$ & 0.33 to 0.48 & 0.82 to 0.84 & 0.36 to 0.53 & 0.45 to 0.85 & -0.24 to & -0.26 to -0.48 \\
\hline $\begin{array}{l}\text { Independent } \\
\text { judiciary (0.15) }\end{array}$ & -0.04 to 0.34 & 0.15 to 0.82 & -0.05 to & 0.11 to 0.84 & -0.06 to & -0.26 to -0.63 \\
\hline $\begin{array}{l}\text { Court efficiency } \\
\text { (0.64) }\end{array}$ & 0.16 & 0.71 to 0.86 & 0.17 to 0.24 & 0.79 to 0.84 & -0.24 to & -0.26 to -0.65 \\
\hline
\end{tabular}




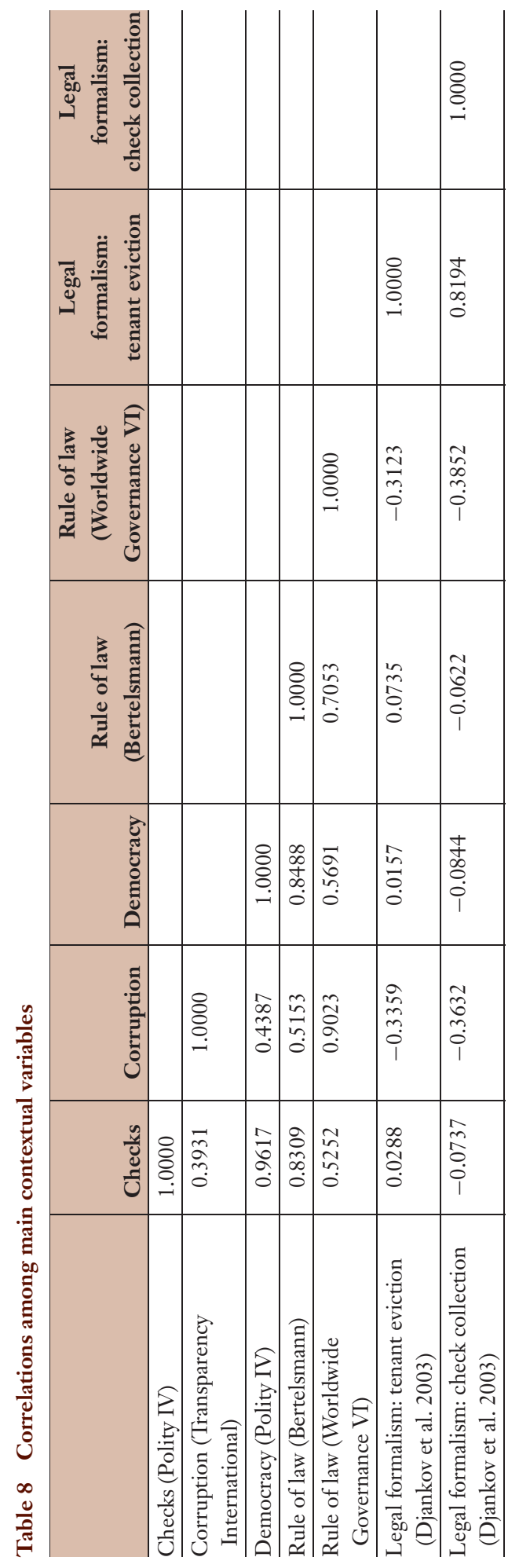




\section{DISCLOSURE STATEMENT}

The authors are not aware of any biases that might be perceived as affecting the objectivity of this review.

\section{LITERATURE CITED}

Acemoglu D, Johnson S, Robinson J. 2001. The colonial origins of comparative development: an empirical investigation. Am. Econ. Rev. 5:1369-401

Acemoglu D, Johnson S, Robinson J. 2005. Institutions as the fundamental cause of long-run growth. In Handbook of Economic Growth, Vol. 1A, ed. P Aghion, S Durlauf, pp. 385-472. Amsterdam: North Holland

Acemoglu D, Johnson S. 2005. Unbundling institutions. F. Polit. Econ. 113(5):949-95

Ades A, Di Tella R. 1997. Rents, competition, and corruption. Am. Econ. Rev. 84(4):982-93

Alchian A. 1965. Some economics of property rights. Il Polit. 30(4):816-29

Alchian A, Demsetz H. 1973. The property rights paradigm. F. Econ. Hist. 33:16-27

Alesina A, Özler N, Roubini N, Swagel P. 1996. Political instability and economic growth. 7. Econ. Growth 1:189-211

Alston LJ, Schneider R. 1996. The determinants and impact of property rights: land titles on the Brazilian frontier. 7. Law Econ. Organ. 12(1):25-61

Anderson TL, Hill PJ. 1975. The evolution of property rights: a study of the American West. 7. Law Econ. 18:163-79

Bardhan P. 1997. Corruption and development: A review of issues. F. Econ. Lit. 35(3):1320-46

Barro R. 1996. Democracy and growth. 7. Econ. Growth 1:1-27

Barzel Y. 1997. Economic Analysis of Property Rights. New York: Cambridge Univ. Press. 2nd ed.

Beck T, Demirgüç-Kunt A, Levine R. 2001. Legal theories of financial development. Oxf. Rev. Econ. Polit. 17:483-501

Belton R. 2005. Competing definitions of the rule of law: implications for practitioners. Carnegie Pap. Rule of Law Ser. \#55. Washington, DC: Carnegie Endow. Int. Peace

Besley T. 1995. Property rights and investment incentives: theory and evidence from Ghana. 7. Polit. Econ. 103(5):903-77

Bhagwati J. 1982. Directly unproductive profit-seeking (DUP) activities. 7. Polit. Econ. 90(51):988-1002

Black B, Kraakman R, Tarassova A. 2000. Russian privatization and corporate governance: What went wrong? Stanford Law Rev. 52:1755-6

Botero J, Djankov S, La Porta R, Lopez-de-Silanes F. 2004. The regulation of labor. Q. 7 . Econ. 119(4):1339-82

Broz L, Weymouth S. 2007. Interests versus institutions as determinants of property rights: evidence from survey data. Work. pap., Dep. Polit. Sci., Univ. Calif. San Diego

Buchanan J, Tullock G. 1962. The Calculus of Consent: Logical Foundations of Constitutional Democracy. Ann Arbor: Univ. Mich. Press

Bueno de Mesquita B, Smith A, Siverson R, Morrow J. 2003. The Logic of Political Survival. Cambridge, MA: MIT Press

Buscaglia E. 1998. Obstacles to judicial reform in Latin America. In Fustice Delayed, Fudicial Reform in Latin America, ed. E Jarquín, F Carrillo, pp. 15-30. Washington, DC: Inter-Am. Dev. Bank

Buscaglia E, Ulen T. 1995. A quantitative analysis of the judicial sectors in Latin America. Presented at Annu. Meet. Am. Law and Econ. Assoc., May 12-13 
Campos JE. 2001. Corruption: The Boom and Bust of East Asia. Quezon City, Philippines: Ateneo Univ. Press

Campos JE, Lien D, Pradhan S. 1999. The impact of corruption on investment: predictability matters. World Dev. 27(6):1059-67

Carothers T, ed. 2006. Promoting the Rule of Law Abroad: In Search of Knowledge. Washington, DC: Carnegie Endow. Int. Peace

Cass R. 2001. The Rule of Law in America. Baltimore, MD: Johns Hopkins Univ. Press

Cheung S. 1963. Private property rights and sharecropping. F. Polit. Econ. 76:1107-22

Cheung S. 1969. A Theory of Share Tenancy. Chicago: Univ. Chicago Press

Clague C, Keefer P, Knack S, Olson M. 1996. Property and contract rights in autocracies and democracies. F. Econ. Growth 1:243-45

Clague C, Keefer P, Knack S, Olson M. 1999. Contract-intensive money: contract enforcement, property rights, and economic performance. F. Econ. Growth 4(2):185-211

Claessens S, Laeven L. 2003. Financial development, property rights and growth. F. Financ. 58(6):2401-36

Coase R. 1960. The problem of social cost. 7. Law Econ. 3:1-44

Collier P. 1999. On the economic consequences of civil war. Oxf. Econ. Pap. 51:168-83

Collier P, Elliott L, Hegre H, Hoeffler A, Reynol-Querol M. 2003. Breaking the Conflict Trap: Civil War and Development Policy. New York: Oxford Univ. Press

Collier P, Hoeffler A, Soederbaum M. 2006. Post-conflict risks. Work. pap., Cent. Stud. Afr. Econ., Dep. Econ., Univ. Oxford

Cox G, McCubbins M. 2001. The institutional determinants of economic policy choice. In Presidents, Parliaments and Policy, ed. S Haggard, M McCubbins, pp. 21-63. New York: Cambridge Univ. Press

Dam K. 2006. The Law-Growth Nexus: The Rule of Law and Economic Development. Washington, DC: Brookings Inst.

Demirgüç-Kunt A, Levine R. 2001. Financial Structure and Economic Growth: A Cross-country Comparison of Banks, Markets, and Development. Cambridge, MA: MIT Press

Demsetz H. 1967. Toward a theory of property rights. Am. Econ. Rev. 57:347-59

de Soto H. 2000. The Mystery of Capital, Why Capitalism Triumphs in the West and Fails Everywhere Else. New York: Basic Books

Dicey AV. 1982. Introduction to the Study of the Law of the Constitution. Indianapolis, IN: Liberty Fund

Dixit A. 2004. Lawlessness and Economics, Alternative Modes of Governance. Oxford, UK: Oxford Univ. Press

Djankov S, La Porta R, Lopez-de-Silanes F, Shleifer A. 2002. The regulation of entry. Q. F. Econ. 117(1):1-37

Djankov S, La Porta R, Lopez-de-Silanes F, Shleifer A. 2003. Courts. Q. F. Econ. 118:457-522

Domingo P. 2000. Judicial independence: the politics of the Supreme Court in Mexico. F. Latin Am. Stud. 32(3):705-35

Easterly W, Levine R. 2003. Tropics, germs, and crops: how endowments influence economic development. 7. Monetary Econ. 50(1):3-39

Fearon J, Laitin D. 2003. Ethnicity, insurgency, and civil war. Am. Polit. Sci. Rev. 97(1):75-90

Feld L, Voigt S. 2003. Economic growth and judicial independence: cross-country evidence using a new set of indicators. Eur. 7. Polit. Econ. 19(3):497-527

Ferejohn J. 1999. Independent judges, dependent judiciary: explaining judicial independence. S. Calif. Law Rev. 72:353-84

Ferejohn J, Pasquino P. 2003. Rule of democracy and rule of law. In Democracy and the Rule of Law, ed. J Maravall, A Przeworski, pp. 242-60. Cambridge, UK: Cambridge Univ. Press 
Fields E. 2004. Property rights, community public goods and household time allocation in urban squatter communities. William Mary Law Rev. 45(3):837-87

Fields E. 2005. Property rights and investment in urban slums. 7. Eur. Econ. Assoc. Pap. Proc. $3(2-3)$

Fields E. 2008. Entitled to work: urban tenure security and labor supply in Peru. Q. F. Econ. In press

Fisman R. 2001. Estimating the value of political connections. Am. Econ. Rev. 91(4):1095-102

Flournoy M, Pan M. 2002. Dealing with demons: justice and reconciliation. Washington Q. 25(4):111-23

Furubotn E, Pejovich S. 1972. Property rights and economic theory: a survey of recent literature. F. Econ. Lit. 10(4):1137-62

Galiani S, Schargrodsky E. 2006. Property rights for the poor: effects of land titling. Work. pap., Univ. San Andres, Buenos Aires, Argentina

Gerring J, Bond P, Barndt W, Moreno C. 2005. Democracy and economic growth: a historical perspective. World Polit. 57(3):323-64

Ginsburg T. 2003. Judicial Review in New Democracies, Constitutional Courts in Asian Cases. Cambridge, UK: Cambridge Univ. Press

Glaeser E, LaPorta R, Lopez-de-Silanes F, Shleifer A. 2004. Do institutions cause growth? 7. Econ. Growth 9:271-303

Glaeser E, Shleifer A. 2002. Legal origins. Q. F. Econ. 117:1193-230

Gourevitch P. 2003. The politics of corporate governance regulation. Yale Law F. 112:1829-80

Gourevitch P, Shinn J. 2005. Political Power and Corporate Control: the New Global Politics of Corporate Governance. Princeton, NJ: Princeton Univ. Press

Greif A. 1993. Contract enforcement and economic institutions in early trade: the Mahgribi traders' coalition. Am. Econ. Rev. 83:525-48

Greif A. 1997. On the interrelations and economic implications of economic, social, political and normative factors: reflections from two late medieval societies. In The Frontiers of the New Institutional Economics, ed. J Drobak, J Nye, pp. 57-84. San Diego: Academic

Greif A, Milgrom P, Weingast B. 1994. Coordination, commitment and enforcement: the case of the merchant guild. F. Polit. Econ. 102(4):745-76

Grossman H, Kim M. 1995. Swords or plowshares? A theory of the security of claims to property. F. Polit. Econ. 103:1275-88

Haber S, Razo M, Maurer N. 2003. The Politics of Property Rights: Political Instability, Credible Commitments and Economic Growth in Mexico, 1876-1929. New York: Cambridge Univ. Press

Hall RE, Jones CI. 1999. Why do some countries produce so much more output per worker than others? Q. F. Econ. 114:83-116

Hammergren L. 2007. Envisioning Reform, Improving Fudicial Performance in Latin America. University Park: Penn. State Univ. Press

Hanssen F. 1999. Appointed courts, elected courts, and public utility regulation: judicial independence and the energy crisis. Bus. Polit. 1(2):179-201

Hayek FA. 1973. Law, Legislation, and Liberty. Vol. 1, Rules and Order. Chicago: Univ. Chicago Press

Hayek FA. 1978. The Road to Serfdom. Chicago: Univ. Chicago Press

Helmke G. 2002. The logic of strategic defection: court-executive relations in Argentina under dictatorship and democracy. Am. Polit. Sci. Rev. 96(2):291-303

Helpman E. 2004. The Mystery of Economic Growth. Cambridge, MA: Harvard Univ. Press

Henisz WJ. 2000a. The institutional environment for economic growth. Econ. Polit. 12(1):1-31 
Henisz WJ. 2000b. The institutional environment for multinational investment. F. Law Econ. Organ. 16(2):334-64

Henisz WJ. 2002. The institutional environment for infrastructure investment. Ind. Corp. Change 11(2):355-89

Henisz WJ. 2004. Political institutions and policy volatility. Econ. Polit. 16(1):1-27

Henisz WJ, Zelner BA. 2001. The institutional environment for telecommunications investment. F. Econ. Manag. Strategy 10(1):123-48

Hirshleifer J. 1995. Anarchy and its breakdown. F. Polit. Econ. 103:26-52

Hohe T, Nixon R. 2002. Reconciling justice: "traditional" law and state judiciaries in East Timor. Final Rep. US Inst. Peace

Holmes S. 2003. Lineages of the rule of law. In Democracy and the Rule of Law, ed. M Maravall, A Przeworski, pp. 19-61. Cambridge, MA: Cambridge Univ. Press

Iaryczower M, Spiller P, Tommasi M. 2002. Judicial independence in unstable environments, Argentina 1935-1998. Am. 7. Polit. Sci. 46:699-716

Johnson S, McMillan J, WoodruffC. 2002. Property rights and finance. Am. Econ. Rev. 92:133556

Kang DC. 2002. Crony Capitalism: Corruption and Development in South Korea and the Philippines. New York: Cambridge Univ. Press

Kaufmann D. 2003a. Rethinking Governance: Empirical Lessons Challenge Orthodoxy. Washington, DC: World Bank

Kaufmann D. 2003b. Governance redux: the empirical challenge. Work. pap., World Bank Inst.

Keefer P. 2004. A review of the political economy of governance: from property rights to voice. World Bank Pol. Res. Work. Pap. 3315

Keefer P. 2007. Beyond legal origin and checks and balances: political credibility, citizen information and financial sector development. World Bank Pol. Res. Work. Pap. 4154

Keefer P, Knack S. 2002. Polarization, politics, and property rights: links between inequality and growth. Public Choice 111:127-54

Knack S, Keefer P. 1995. Institutions and economic performance: cross-country tests using alternative institutional measures. Econ. Polit. 7:207-28

Konrad K, Skaperdas S. 1998. Extortion. Economica 65(260):461-77

Kreuger A. 1974. The political economy of a rent-seeking society. Am. Econ. Rev. 64(3):291-303

La Porta R, Lopez-de-Silanes F, Shleifer A, Vishny RW. 1997. Legal determinants of external finance. F. Finance 52:1131-50

La Porta R, Lopez-de-Silanes F, Shleifer A, Vishny RW. 1998. Law and finance. F. Polit. Econ. 106:1113-55

La Porta R, Lopez-de-Silanes F, Shleifer A, Vishny RW. 1999. The quality of government. 7. Law Econ. Organ. 15:222-79

La Porta R, Lopez-de-Silanes F, Shleifer A, Vishny RW. 2000. Investor protection and corporate governance. F. Financ. Econ. 58:3-27

La Porta R, Lopez-de-Silanes F, Shleifer A, Vishny RW. 2002. Investor protection and corporate valuation. F. Finance 57:1147-70

La Porta R, Lopez-de-Silanes F, Pop-Eleches C, Shleifer A. 2004. Judicial checks and balances. 7. Polit. Econ. 112:445-70

Li S, Lian P. 2001. Governance and investment in China. In Corruption: The Boom and Bust of East Asia, ed. JE Campos, pp. 69-100. Quezon City, Philippines: Ateneo Univ. Press

Libecap G. 1989. Contracting for Property Rights. New York: Cambridge Univ. Press

MacIntyre A. 2001. Investment, property rights and corruption in Indonesia. In Corruption: The Boom and Bust of East Asia, ed. JE Campos, pp. 25-44. Quezon City: Ateneo Univ. Press 
MacIntyre A. 2003. The Power of Institutions: Political Architecture and Governance. Ithaca, NY: Cornell Univ. Press

Mauro P. 1995. Corruption and growth. Q. F. Econ. 110(3):681-712

Mauro P. 1998. Corruption and the composition of government. F. Public Econ. 68(88):263-79

McNollgast. 2006. Conditions for judicial independence. 7. Contemp. Legal Iss. 15(1):105-27

McMillan J, Woodruff C. 1999. Dispute prevention without courts in Vietnam. F. Law Econ. Organ. 15(3):637-58

McGuire M, Olson M. 1996. The economics of autocracy and majority rule: the invisible hand and the use of force. F. Econ. Lit. 34:72-96

McMillan J, Zoido P. 2004. How to subvert democracy: Montesinos in Peru. CESIFO Work. Pap. 1173

Milgrom P, North D, Weingast B. 1990. The role of institutions in the revival of trade: the law merchant, private judges, and the Champagne fairs. Econ. Polit. 2:1-23

Moreno E, Crisp B, Shugart M. 2003. The accountability deficit in Latin America. In Democratic Accountability in Latin America, ed. S Mainwaring, C Welna, pp. 79-131. Oxford, UK: Oxford Univ. Press

Narayan D, Patel R, Schafft K, Rademacher A, Koch-Schulte S. 2000. Voices of the Poor. New York: Oxford Univ. Press

North D. 1981. Structure and Change in Economic History. New York: WW Norton

North D. 1990. Institutions, Institutional Change and Economic Performance. Cambridge, UK: Cambridge Univ. Press

North D, Thomas R. 1973. The Rise of the Western World: A New Economic History. New York: Cambridge Univ. Press

North D, Weingast B. 1989. Constitutions and commitment: the evolution of institutions governing public choice in seventeenth-century England. F. Econ. Hist. 44:803-32

Olson M. 1993. Dictatorship, democracy and development. Am. Polit. Sci. Rev. 87:567-76

Pellegrini L, Gerlagh R. 2004. Corruption's effect on growth. Kyklos 57(3):426-56

Petrova M, Bates R. 2007. Political expectations and economic performance. Presented at Annu. Meet. Am. Polit. Sci. Assoc., Aug. 29-Sep. 2, Chicago

Popkin M. 2000. Peace without Fustice: Obstacles to Building the Rule of Law in El Salvador. University Park: Penn. State Univ. Press

Prillaman W. 2000. The fudiciary and Democratic Decay in Latin America, Declining Confidence in the Rule of Law. Westport, CT: Praeger

Przeworski A. 2004. Institutions matter? Gov. Opposition 39(4):527-40

Przeworski A, Alvarez M, Cheibub J, Limongi F. 2000. Democracy and Development: Political Institutions and Well-Being in the World, 1950-1990. Cambridge, UK: Cambridge Univ. Press

Rajan R, Zingales L. 2003. The great reversals: the politics of financial development in the twentieth century. F. Financ. Econ. 69:5-50

Rajan R, Zingales L. 2004. Saving Capitalism from the Capitalists. Princeton, NJ: Princeton Univ. Press

Ramseyer JM. 1994. The puzzling (in)dependence of the courts: a comparative approach. 7. Legal Stud. 23(2):721-48

Ramseyer JM, Rasmussen EB. 2001. Why are Japanese judges so conservative in politically charged cases? Am. Polit. Sci. Rev. 95(2):331-44

Rauch J. 2001. Business and social networks in international trade. F. Econ. Lit. 39:1177-203

Reinikka R. 2001. Recovery in service delivery: evidence from schools and health center. In Uganda's Recovery: The Role of Farms, Firms, and Government, ed. R Reinikka, P Collier, pp. 343-69. Washington, DC: World Bank 
Reinikka R, Svensson J. 2002. Measuring and understanding corruption at the micro level. Work. pap., World Bank Dev. Res. Group

Rock MT, Bonnett H. 2004. The comparative politics of corruption: accounting for the East Asian paradox in empirical studies of corruption, growth and investment. World Dev. 32(6):999-1017

Rodrik D. 1999. Where did all the growth go? External shocks, social conflict, and growth collapses. F. Econ. Growth 4:385-412

Rodrik D, Subramanian A, Trebbi F. 2002. Institutions rule: the primacy of institutions over geography and integration in economic development. Natl. Bur. Econ. Res. Work. Pap. 9305

Roe M. 2003. Political Determinants of Corporate Governance: Political Context, Corporate Impact. New York: Oxford Univ. Press

Root H. 1994. Fountain of Privilege: Political Foundations of Markets in Old Regime France and England. Berkeley: Univ. Calif. Press

Russell P. 2001. Towards a general theory of judicial independence. In Fudicial Independence in the Age of Democracy: Critical Perspectives from Around the World, ed. P Russell, D O'Brian, pp. 1-24. Charlottesville: Univ. Press Virginia

Sachs J. 2003. Institutions don't rule: direct effects of geography on per capita income. Work. Pap. 9490. http://www.nber.org/papers/w9490

Samuels K. 2006. Rule of law reform in postconflict countries. World Bank Soc. Dev. Pap., Confl. Prevent. Reconstruct., No. 37

Schedler A, Diamond L, Plattner M, eds. 1999. The Self-Restraining State: Power and Accountability in New Democracies. Boulder, CO: Lynne Reiner

Schultz KA, Weingast BR. 2003. The democratic advantage: institutional foundations of financial power in international competition. Int. Organ. 57:3-42

Scully G. 1988. The institutional framework and economic development. F. Polit. Econ. 96:65262

Shapiro M. 1981. Courts. Chicago: Chicago Univ. Press

Shleifer A, Vishny R. 1993. Corruption. Q. F. Econ. 108:599-617

Shleifer A, Vishny R. 1998. The Grabbing Hand: Government Pathologies and Their Cure. Cambridge, MA: Harvard Univ. Press

Sieder R. 2001. Rethinking citizenship: reforming the law in postwar Guatemala. In States and Imagination: Ethnographic Explorations of the Postcolonial State, ed. T Hansen, F Stepputat, pp. 203-20. Durham, NC: Duke Univ. Press

Siems M. 2006. Legal origins: reconciling law and finance and comparative law. Work. Pap. No. 321, Cent. Bus. Res., Univ. Cambridge

Svensson J. 1998. Investment, property rights and political instability: theory and evidence. Eur. Econ. Rev. 42:1317-41

Stasavage D. 2002. Private investment and political institutions. Econ. Polit. 14:41-63

Stasavage D. 2003. Public Debt and the Birth of the Democratic State: France and Britain. New York: Cambridge Univ. Press

Tanzi V, Davoodi H. 1997. Corruption, public investment and growth. Int. Monetary Fund Work. Pap.

Tiede L. 2006. Judicial independence: often cited, rarely understood. F. Contemp. Legal Iss. 15:129-61

Tiede L. 2007. (Mis)interpreting the rule of law: an assessment of legal indicators. Work. pap., Dep. Polit. Sci., Univ. Calif. San Diego

Transparency International. 2007. Global Corruption Report 2007. Cambridge, UK: Cambridge Univ. Press 
Treisman D. 2000. The causes of corruption; a cross-national study. F. Public Econ. 76(3):399_ 457

Treisman D. 2007. What have we learned about the causes of corruption from ten years of cross-national empirical research? Annu. Rev. Polit. Sci. 10:211-44

Tsai K. 2002. Back-Alley Banking: Private Entrepreneurs in China. Ithaca, NY: Cornell Univ. Press

Tsebelis G. 2002. Veto Players: How Political Institutions Work. Princeton, NJ: Princeton Univ. Press

US General Accounting Office. 2001. Soviet Union, U.S. rule of law assistance has had limited impact. GAO 01-354, Washington, DC

Upham F. 2006. Mythmaking in the rule-of-law orthodoxy. In Promoting the Rule of Law Abroad, ed. T Carrothers, pp. 75-104. Washington, DC: Carnegie Endow. Int. Peace

Vinjamuri L, Snyder J. 2004. Advocacy and scholarship in the study of international war crimes tribunals and transitional justice. Annu. Rev. Polit. Sci. 7:345-62

Walter B. 1997. The critical barrier to civil war settlement. Int. Organ. 51(3):335-64

Wei SJ. 1997. How taxing is corruption on international investors? Work. Pap. \#6030, Natl. Bur. Econ. Res.

Weingast B. 1995. The economic role of political institutions. F. Law Econ. Organ. 7:1-31

Weingast B. 1997. The political foundations of democracy and the rule of law. Am. Polit. Sci. Rev. 91(2):245-63

Williamson O. 1971. The vertical integration of production: market failure considerations. Am. Econ. Rev. 61:112-23

Williamson O. 1985. The Economic Institutions of Capitalism: Firms, Markets, Relational Contracting. New York: Free Press

World Bank. 2006. World Bank announces strategy to combat corruption. World Bank Press Release No. 2006/358/EXC. June 11

World Bank and European Bank for Reconstruction and Development. 2007. Business environment and enterprise performance survey. http://info.worldbank.org/governance/beeps/. Accessed Sep. 22, 2007

Zak P, Knack P. 2001. Trust and growth. Econ. F. 111:295-321 


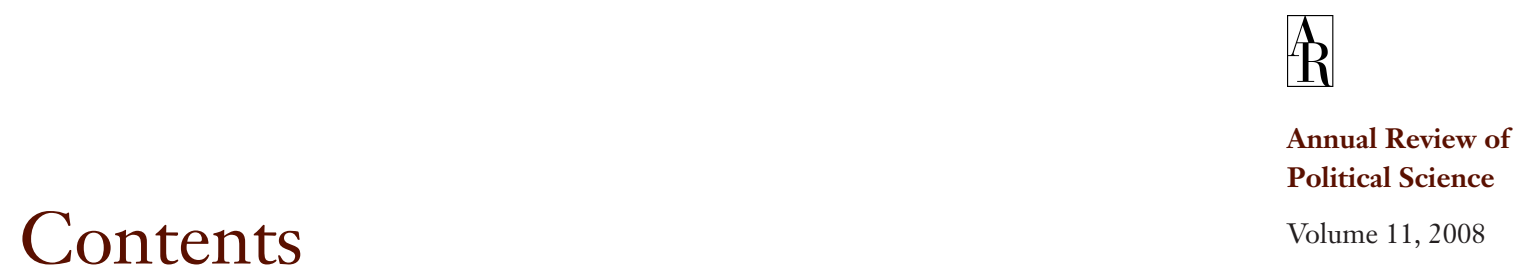

State Failure

Robert H. Bates ............................................................

The Ups and Downs of Bureaucratic Organization

Fohan P. Olsen ...................................................... 13

The Relationships Between Mass Media, Public Opinion, and Foreign

Policy: Toward a Theoretical Synthesis

Matthew A. Baum and Philip B.K. Potter ........................................ 39

What the Ancient Greeks Can Tell Us About Democracy

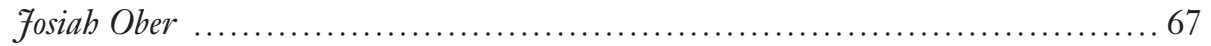

The Judicialization of Mega-Politics and the Rise of Political Courts

Ran Hirschl ................................................... 93

Debating the Role of Institutions in Political and Economic

Development: Theory, History, and Findings

Stanley L. Engerman and Kenneth L. Sokoloff ....

The Role of Politics in Economic Development

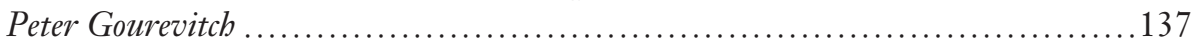

Does Electoral System Reform Work? Electoral System Lessons from

Reforms of the 1990s

Ethan Scheiner

The New Empirical Biopolitics

Fobn R. Alford and Fobn R. Hibbing

The Rule of Law and Economic Development

Stephan Haggard, Andrew MacIntyre, and Lydia Tiede .........................205

Hiding in Plain Sight: American Politics and the Carceral State

Marie Gottschalk ...........................................................235

Private Global Business Regulation

David Vogel ....................................................... 261

Pitfalls and Prospects in the Peacekeeping Literature

Virginia Page Fortna and Lise Morjé Howard 
Discursive Institutionalism: The Explanatory Power of Ideas and Discourse

Vivien A. Schmidt

The Mobilization of Opposition to Economic Liberalization

Kenneth M. Roberts

Coalitions

Macartan Humphreys

The Concept of Representation in Contemporary Democratic Theory

Nadia Urbinati and Mark E. Warren

What Have We Learned About Generalized Trust, If Anything?

Peter Nannestad

Convenience Voting

Paul Gronke, Eva Galanes-Rosenbaum, Peter A. Miller, and Daniel Toffey

Race, Immigration, and the Identity-to-Politics Link

Taeku Lee

Work and Power: The Connection Between Female Labor Force Participation and Female Political Representation

Torben Iversen and Frances Rosenbluth

Deliberative Democratic Theory and Empirical Political Science

Dennis F. Thompson

Is Deliberative Democracy a Falsifiable Theory?

Diana C. Mutz

The Social Processes of Civil War: The Wartime Transformation of Social Networks Elisabeth Jean Wood

Political Polarization in the American Public

Morris P. Fiorina and Samuel 7. Abrams.

\section{Indexes}

Cumulative Index of Contributing Authors, Volumes 7-11

Cumulative Index of Chapter Titles, Volumes 7-11

\section{Errata}

An online log of corrections to Annual Review of Political Science articles may be found at http://polisci.annualreviews.org/ 